\title{
7
}

\section{Organophosphorus Pesticides Analysis}

\author{
Margarita Stoytcheva and Roumen Zlatev \\ Universidad Autónoma de Baja California, Instituto de Ingeniería \\ Mexico
}

\section{Introduction}

The organophosphorus (OP) pesticides are synthetic esters, amides, or thiol derivatives of the phosphoric, phosphonic, phosphorothioic, or phosphonothioic acids (Corbett et al., 1984; Eto, 1974; Gupta, 2006; Hassall, 1982; Quin, 2000). The structural diversity of this family of compounds is reflected in their physicochemical and biological properties: vapour pressure, solubility in water, chemical stability and toxicity (Corbett et al., 1984; Hassall, 1982; WHO, 1986), which determine their specific application (Hassal, 1982). Compared to the mostly banned in U.S. and Europe organochlorine pesticides, the OP ones are less persistent in the environment, are not subject of bioaccumulation and biomagnification, and do not release toxic break down products (Krieger, 2001). These features justify their application in the agricultural and veterinary practices of the modern world. In 1999 the OP insecticides represented $\approx 37 \%$ of the pesticides in use at a global scale (Table 1) and $72 \%$ of the insecticides used in U.S. (Kiely et al., 2004). The top ten OP insecticides active ingredients include malathion, chlorpyrifos, terbufos, diazinon, methyl-parathion, phorate, acephate, phosmet, azinphos-methyl, and dimethoate (Kiely et al., 2004).

\begin{tabular}{|c|c|c|c|c|c|c|c|c|c|}
\hline $\begin{array}{c}\text { Consumption, } \\
\text { tons }\end{array}$ & \multicolumn{1991}{|c|}{ Year } \\
\cline { 2 - 11 } & $\mathbf{1 9 9 0}$ & $\mathbf{1 9 9 1}$ & $\mathbf{1 9 9 2}$ & $\mathbf{1 9 9 3}$ & $\mathbf{1 9 9 4}$ & $\mathbf{1 9 9 5}$ & $\mathbf{1 9 9 6}$ & $\mathbf{1 9 9 7}$ & $\mathbf{1 9 9 8}$ \\
\hline OP insecticides & 49446 & 48919 & 52472 & 53961 & 50321 & 63998 & 66620 & 71338 & 65578 \\
\hline Pesticides total & 318528 & 311415 & 304063 & 276699 & 307901 & 327488 & 320934 & 324942 & 193491 \\
\hline$\%$ OP & 15.52 & 15.70 & 17.25 & 19.50 & 16.34 & 19.54 & 20.76 & 21.95 & 33.89 \\
\hline
\end{tabular}

\begin{tabular}{|c|c|c|c|c|c|c|c|c|c|}
\hline $\begin{array}{c}\text { Consumption, } \\
\text { tons }\end{array}$ & \multicolumn{10}{|c|}{ Year } \\
\cline { 2 - 11 } & $\mathbf{1 9 9 9}$ & $\mathbf{2 0 0 0}$ & $\mathbf{2 0 0 1}$ & $\mathbf{2 0 0 2}$ & $\mathbf{2 0 0 3}$ & $\mathbf{2 0 0 4}$ & $\mathbf{2 0 0 5}$ & $\mathbf{2 0 0 6}$ & $\mathbf{2 0 0 7}$ \\
\hline OP insecticides & 62653 & 48685 & 32507 & 13829 & 15495 & 20944 & 26724 & 18629 & 12377 \\
\hline Pesticides total & 167912 & 252176 & 245064 & 179724 & 180897 & 202817 & 232515 & 234688 & 105940 \\
\hline \% OP & 37.31 & 19.31 & 13.26 & 7.69 & 8.56 & 10.33 & 11.49 & 7.94 & 11.68 \\
\hline
\end{tabular}

Table 1. Summary of the annual OP insecticides consumption (metric tons of active ingredients) and of the annual total pesticides consumption (metric tons of active ingredients), according to the Statistics Division of the Food and Agriculture Organization of the United Nations (FAOSTAT, 1990-2007).

Nevertheless, because of the high acute toxicity of the OP pesticides (Eddleston et al., 2008; Gupta, 2006; Roberts \& Aaron, 2007), as well as because of the registered chronic effects (Gupta, 2006), the OP pesticides residues limits in food, drinking water and environmental 
samples are subject of regulation and control. The European Council Directive 98/83/EC on the quality of water intended for human consumption (Council Directive 98/83/EC, 1998) sets the limit value of the individual pesticides in drinking water at $0.1 \mu \mathrm{g} \mathrm{L}^{-1}$ and that of the total pesticides at $0.5 \mu \mathrm{g} \mathrm{L}{ }^{-1}$. According to the U.S. Environmental Protection Agency Office of Ground Water and Drinking Water (OGWDW), the health advisory levels for some OP pesticides in drinking water are: diazinon $3 \mu \mathrm{g} \mathrm{L}-1$, parathion-methyl $2 \mu \mathrm{g} \mathrm{L}-1$, disulfoton 1 $\mu \mathrm{g}$ L-1, fenamiphos $2 \mu \mathrm{g}$ L-1, etc., the following 22 OP pesticides being on the U. S. National Pesticide Survey List: diazinon, dichlorfos, dicrotophos, dimethoate, diphenamiphos, sulfone, disulfoton, disulfoton sulfone, disulfoton sulfoxide, fenamiphos sulfone, fenamiphos sulfoxide, fenitrothion, methyl paraoxon, mevinphos, monocrotophos, omethoate, parathion ethyl, phosphamidon, stirophos, terbufos, tetrachlorvinphos, and merphos. At this time, four European Council Directives (Council Directive 76/895/EEC, 1976; Council Directive 86/362/EEC, 1986; Council Directive 86/363/EEC, 1896; Council Directive 90/642/EEC, 1990) set the maximum residue limits (MRLs) for pesticides in food commodities. Other organisations involved in establishing the pesticide residues levels are the World Health Organization (WHO), the Food and Agricultural Organization of the United Nations (FAO), the Codex Alimentarius Commission, and the U.S. Environmental Protection Agency (EPA). Currently, EPA is reassessing pesticide residue limits in food to ensure that they met the safety standard established by the Food Quality Protection Act of 1996 (FQPA, 1996). Some relevant data on MRLs are presented in Table 2.

\begin{tabular}{|c|c|c|c|c|c|}
\hline \multirow{2}{*}{ Pesticide } & \multicolumn{2}{|c|}{$\begin{array}{c}\text { MRLs (varie according } \\
\text { to the product, } \mathrm{mg} \mathrm{kg}^{-1} \text { ) }\end{array}$} & \multirow{2}{*}{ Pesticide } & \multicolumn{2}{|c|}{$\begin{array}{c}\text { MRLs (varie according } \\
\text { to the product, } \mathrm{mg} \mathrm{kg}^{-1} \text { ) }\end{array}$} \\
\cline { 2 - 3 } \cline { 5 - 6 } & EC & Codex & & EC & Codex \\
\hline acephate & $0.05-0.2$ & $0.01-50$ & malathion & $0.02-8$ & $0.01-20$ \\
\hline $\begin{array}{c}\text { azinphos- } \\
\text { methy }\end{array}$ & $0.01-0.5$ & $0.05-10$ & $\begin{array}{c}\text { Parathion- } \\
\text { methyl }\end{array}$ & $0.02-5$ & $0.05-1$ \\
\hline chlorpyrifos & $0.05-5$ & $0.01-5$ & phorate & $0.02-1$ & $0.05-0.1$ \\
\hline diazinon & $0.01-5$ & $0.01-5$ & phosmet & $0.05-10$ & $0.05-0.2$ \\
\hline dimethoate & $0.02-2$ & $0.05-5$ & terbufos & 0.01 & $0.05-0.3$ \\
\hline
\end{tabular}

Table 2. Maximum residue limits (MRLs) of pesticides in or on food and feed of plant and animal origin, set by the European Council (EC) regulation No 396/2005 (Reg. EC No 396/2005), and MRLs in food set by the Codex Alimentarius Commission (Codex pesticides residues in food online database, 1996)

The MRL of a number of OP pesticides is set up at or about the limit of their determination by the currently available analytical methods. Thus, in this work are reviewed the developed during the last years (2005-2011) procedures for OP pesticides analysis, including sample pretreatment and determination in the context of the implementation of modern reliable, high sensitive, selective, rapid, cost-effective and environmental friendly analytical techniques for OP pesticides residues quantification. This overview comments on their advantages and limitations.

\section{Organophosphorus pesticides analysis}

The revision of 115 original publications covering the period 2005-2011 and of 40 reviews demonstrated that the techniques applied for OP pesticides analyses are mostly 
chromatographic (gas chromatography and liquid chromatography), electrochemical, immunochemical, and biosensors based ones (Fig. 1).

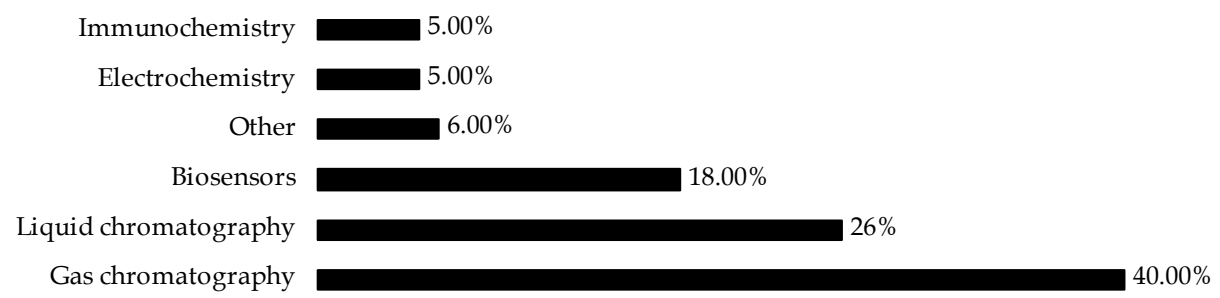

Fig. 1. Techniques applied for OP pesticides analysis (2005-2011)

\subsection{Chromatographic methods for OP pesticides analysis}

Chromatography is considered as a powerful analytical technique regarding the analysis of complex matrices. However, the method requires sample pretreatment, which reaches $60 \%$ of the total analysis time. Hence, the development of time-saving, jointly with effective and economic procedures is of crucial importance. Some recent publications provide an overview of the promising techniques: solid-phase extraction, solid-phase microextraction, stir-bar sorptive extraction, matrix solid-phase dispersion, solvent extraction, liquid-phase microextraction, super critical fluid extraction, ultrasonication extraction, microwaveaccelerated extraction, and membrane-assisted methods, applied to various matrices (Beyer \& Biziuk, 2008; Gilbert-López et al., 2009; Hyötyläinen \& Riekkola, 2008; Picó et al., 2007; Pinto et al., 2010; Rial-Otero et al., 2007).

The tendencies in the application of gas chromatography and liquid chromatography to pesticides residues determination in environmental samples and food, together with sample preparation procedures are revised by several authors (Le Doux, 2011; Pareja et al., 2010; Sharma et al., 2010; Yusà et al., 2009). The trends in liquid chromatography-mass spectrometry and liquid chromatography-tandem mass spectrometry development are highlighted in the published in 2007, 2009, and 2010 reviews (Kuster et al., 2009; Malik et al., 2010; Petrovic et al., 2010; Soler \& Picó, 2007).

The original research works devoted to OP pesticides analysis applying various chromatographic techniques: gas chromatography-mass spectrometry (Baugros et al., 2008; Chen \& Huang, 2006; Cortés-Aguado et al., 2008; Cunha et al., 2009; Filho et al., 2010a, 2010b; Hassan et al., 2010; Kolberg et al., 2011; Lavagnini et al., 2011; Lesueur et al., 2008a, 2008b; Li et al., 2011b; Libin et al., 2006; López-Feria et al., 2009; Nguyen et al., 2008; Nguyen et al., 2010; Pang et al., 2006; Rodrigues et al., 2010; Silva et al., 2008; Sinha et al., 2006; Toledano et al., 2010; Wang et al., 2007; Wang et al., 2011; Wu et al., 2011; Yang et al., 2011), gas chromatographytandem mass spectrometry (Barco-Bonilla et al., 2010; Camino-Sánchez et al., 2008; Frenich et al., 2006; Fuentes et al., 2008, 2009; García-Rodríguez et al., 2010; Lee et al., 2008; Qu et al., 2010; Walorczyk, 2008; Walorczyk \& Gnusowski, 2009), gas chromatography-ion trap mass spectrometry (González-Rodríguez et al., 2008; Przybylski \& Hommet, 2008), gas chromatography time-of-flight mass spectrometry (Hernández et al., 2010; Portolés et al., 2011), high performance liquid chromatography (Akkad et al., 2010; Al-Degs et al., 2009; He et al., 2009; Pérez-Ruiz et al., 2005; Wu et al., 2010; Zhu et al., 2007), high performance liquid chromatography-electrospray ionization-mass spectrometry (Sinha et al., 2010), liquid 
chromatography-ion trap-triple stage mass spectrometry (Blasco et al., 2005; Lesueur et al., 2008b), liquid chromatography-mass spectrometry (Inoue et al., 2007; Liu et al., 2005, 2006), liquid chromatography tandem mass spectrometry (Baugros et al., 2008, 2009; Chung \& Chan, 2010; Dagnac et al., 2009; Díaz et al., 2008; Dujaković et al., 2010; García-Valcárcel \& Tadeo, 2009; Hernández et al., 2006; Kujawski \& Namieśnik, 2010; Pang et al., 2006; Pinxteren et al., 2009; Radišić et al., 2009; Salma et al., 2009), and nano-liquid chromatography (Buonasera et al., 2009) comment on the sample preparation procedure, the detection system, and the analytical performances of the method with emphasis on its optimization.

Sample preparation procedures include a large variety of techniques: solid-phase extraction (Al-Degs et al., 2009; Dujaković et al., 2010; Portolés et al., 2011; Wang et al., 2010; Yang et al., 2011; Zhu et al., 2007), solid-phase extraction using carbon nanotubes (López-Feria et al., 2009; Wang et al., 2007), solid-phase microextraction (Chai et al., 2009; Cortés-Aguado et al., 2008; Filho et al., 2010a, 2010b; Tsoutsi et al., 2006), solid-phase microextraction using a new sol-gel hybrid coating (Ibrahim et al., 2010), solid-phase dispersion (Libin et al., 2006; Radišić et al., 2009; Ramos et al., 2009; Silva et al., 2008), headspace-solid-phase microextraction (Rodrigues et al., 2010), microwave-assisted extraction coupled to solid-phase extraction or different clean-up methods (Fuentes et al., 2008, 2009), single-drop microextraction (Ahmadi et al., 2006; Xiao et al., 2006; Pinheiro et al., 2009), cloud point extraction coupled with ultrasonic-assisted back-extraction (Zhao et al., 2011), solvent extraction (Dugo et al., 2005; Fenoll et al., 2007; Georgakopoulos et al., 2009; González-Rodríguez et al., 2008; He et al., 2009; Hernández et al., 2006; Liu et al., 2005; Pang et al., 2006; Sinha et al., 2006, 2010; Walorczyk \& Gnusowski, 2009), accelerated solvent extraction and gel permeation clean-up (Wu et al., 2011), membrane-assisted solvent extraction (Pinxteren et al., 2009), ultrasonic solvents extraction (García-Valcárcel et al., 2009; Lesueur et al., 2008b; Wu et al., 2010), liquidliquid extraction (Kujawski \& Namieśnik, 2010; Nguyen et al., 2010), low density miniaturized homogeneous liquid-liquid extraction (Hassan et al., 2010), liquid-liquid extraction and low temperature purification (Pinho et al., 2010), liquid extraction and programmed temperature vaporization (García-Rodríguez et al., 2010), dispersive liquid-liquid microextraction (Cunha et al., 2009), pressurized liquid extraction (Barco-Bonilla et al., 2010; Baugros et al., 2009; Blasco et al., 2005), hollow fiber sorptive extraction (Li et al., 2011b), hollow fiber-protected liquidphase microextraction (Chen \& Huang, 2006), stir-bar sorptive extraction-thermal desorption (Lavagnini et al., 2011), as well as the developed in 2003 (Anastassiades et al., 2003) quick, easy, cheap, effective, rugged and safe (QuEChERS) method (González-Curbelo et al., 2011; Kolberg et al., 2011; Lee et al., 2008; Lesueur et al., 2008a; Nguyen et al., 2008; Walorczyk, 2008). Some of these techniques like solid phase extraction and solid-phase microextraction in particular are commonly accepted. Advantage of the solid phase microextraction is the possibility of automation. Liquid-phase microextraction, as a relatively new procedure, does not find a large application at this time. The developed approaches are intended to reduce the sample preparation time, the solvent consumption and the amount of the sample, and to achieve high selectivity, applying simple, rapid, effective, and inexpensive methods, compatible with modern analytical techniques.

Other methods aimed to ensure a high sensitivity of the determination, in concert with the reliable sample preparation technique, apart of the mentioned above, are: gas chromatography with nitrogen-phosphorus detection (Fenoll et al., 2007; Georgakopoulos et al., 2009; Pagliuca et al., 2005; Ravelo-Pérez et al., 2008), gas chromatography with flame thermionic detection (Tsoutsi et al., 2006), gas chromatography with electron capture detection (Chai \& Tan, 2009; Guardia-Rubio et al., 2007; Ibrahim et al., 2010; Pinho et al., 
2010; Ramos et al., 2009), gas chromatography with flame photometric detection (Ahmadi et al., 2006; Wang \& Du, 2010; Xiao et al., 2006; Zhao et al., 2011), gas chromatography with flame ionization detection (Pinheiro, \& Andrade, 2009), liquid chromatography with electrochemical flow detection (Trojanowicz, 2010), liquid chromatography with UV detection (Buonasera et al., 2009), high performance liquid chromatography with UV detection (Zhu et al., 2007), high performance liquid chromatography with fluorimetric detection (Pérez-Ruiz et al., 2005), and high performance liquid chromatography with diode array detection (Wu et al., 2010).

Relevant data collected for the period 2010-2011, revealing the analytical performances of some selected chromatographic methods are summarized in Table 3.

\begin{tabular}{|c|c|c|c|c|}
\hline Pesticide & Detection Method & Sample preparation & LOD & References \\
\hline Atrazine & $\begin{array}{l}\text { LC-MS/MS } \\
\text { GS-MS }\end{array}$ & $\begin{array}{c}\text { SE } \\
\text { TOTAD }\end{array}$ & $\begin{array}{l}0.06 \mu \mathrm{g} \mathrm{L}^{-1} \\
0.05 \mu \mathrm{g} \mathrm{L}^{-1}\end{array}$ & $\begin{array}{c}\text { Sinha et al., } 2010 \\
\text { Toledano et al., } 2010\end{array}$ \\
\hline Chlorpyrifos & $\begin{array}{l}\text { GC-MS } \\
\text { GC-ECD }\end{array}$ & $\begin{array}{l}\text { LLSE } \\
\text { LLE }\end{array}$ & $\begin{array}{l}0.13 \mu \mathrm{g} \mathrm{kg}^{-1} \\
14.0 \mu \mathrm{g} \mathrm{kg}^{-1}\end{array}$ & $\begin{array}{c}\text { Hassan et al., } 2010 \\
\text { Pinho et al., } 2010 \\
\end{array}$ \\
\hline Diazinon & GC-QqQ MS/MS & DSPE & $0.37 \mu \mathrm{g} \mathrm{kg}^{-1}$ & Qu et al., 2010 \\
\hline Dichlorvos & $\begin{array}{c}\text { GC-MS } \\
\text { GC-MS } \\
\text { GC-QqQ MS/MS }\end{array}$ & $\begin{array}{c}\text { ASE } \\
\text { HS-SPME } \\
\text { DSPE }\end{array}$ & $\begin{array}{c}6.00 \mu \mathrm{g} \mathrm{kg}^{-1} \\
3.80 \mu \mathrm{g} \mathrm{L}^{-1} \\
1.50 \mu \mathrm{g} \mathrm{kg}^{-1}\end{array}$ & $\begin{array}{c}\text { Wu et al., } 2011 \\
\text { Rodrigues et al., } 2010 \\
\text { Qu et al., } 2010\end{array}$ \\
\hline Paraoxon & GC-MS & ASE & $1.10 \mu \mathrm{g} \mathrm{kg}^{-1}$ & Wu et al., 2011 \\
\hline Malathion & $\begin{array}{c}\text { GC-MS } \\
\text { GC-MS } \\
\text { GS-MS } \\
\text { GC/PFPD } \\
\text { GC-MS } \\
\text { GC-QqQ MS/MS }\end{array}$ & $\begin{array}{c}\text { ASE } \\
\text { SPME } \\
\text { TOTAD } \\
\text { SPE } \\
\text { SPME } \\
\text { DSPE }\end{array}$ & $\begin{array}{c}0.20 \mu \mathrm{g} \mathrm{kg}^{-1} \\
0.03 \mu \mathrm{g} \mathrm{L}^{-1} \\
0.07 \mu \mathrm{g} \mathrm{L}^{-1} \\
0.03 \mu \mathrm{g} \mathrm{L}^{-1} \\
2.00 \mu \mathrm{g} \mathrm{kg}^{-1} \\
0.22 \mu \mathrm{g} \mathrm{kg}^{-1}\end{array}$ & $\begin{array}{c}\text { Wu et al., } 2011 \\
\text { Filho et al., 2010b } \\
\text { Toledano et al., } 2010 \\
\text { Wang et al., } 2010 \\
\text { Filho et al., 2010a } \\
\text { Qu et al., 2010 }\end{array}$ \\
\hline Parathion & $\begin{array}{c}\text { GC-MS } \\
\text { GC-MS } \\
\text { HPLC-DAD } \\
\text { GS-MS } \\
\text { GC/PFPD } \\
\text { GC-QqQ MS/MS }\end{array}$ & $\begin{array}{c}\text { ASE } \\
\text { HS-SPME } \\
\text { UASEME } \\
\text { TOTAD } \\
\text { SPE } \\
\text { DSPE } \\
\end{array}$ & $\begin{array}{c}0.20 \mu \mathrm{g} \mathrm{kg}^{-1} \\
4.70 \mu \mathrm{g} \mathrm{L}^{-1} \\
0.10 \mu \mathrm{g} \mathrm{L}^{-1} \\
0.12 \mu \mathrm{g} \mathrm{L}^{-1} \\
0.02 \mu \mathrm{g} \mathrm{L}^{-1} \\
1.50 \mu \mathrm{g} \mathrm{kg}^{-1} \\
\end{array}$ & $\begin{array}{c}\text { Wu et al., } 2011 \\
\text { Rodrigues et al., } 2010 \\
\text { Wu et al., } 2010 \\
\text { Toledano et al., } 2010 \\
\text { Wang et al., } 2010 \\
\text { Qu et al., } 2010 \\
\end{array}$ \\
\hline Parathion-methyl & $\begin{array}{c}\text { GC-MS } \\
\text { GC-MS } \\
\text { HPLC-DAD } \\
\text { GC-MS } \\
\text { GC/PFPD } \\
\text { GC-MS } \\
\text { GC-QqQ MS/MS } \\
\end{array}$ & $\begin{array}{c}\text { ASE } \\
\text { HS-SPME } \\
\text { UASEME } \\
\text { SPME } \\
\text { SPE } \\
\text { SPME } \\
\text { DSPE } \\
\end{array}$ & $\begin{array}{c}0.80 \mu \mathrm{g} \mathrm{kg}^{-1} \\
10.9 \mu \mathrm{g} \mathrm{L}^{-1} \\
0.10 \mu \mathrm{g} \mathrm{L}^{-1} \\
0.02 \mu \mathrm{g} \mathrm{L}^{-1} \\
0.03 \mu \mathrm{g} \mathrm{L}^{-1} \\
5.00 \mu \mathrm{g} \mathrm{kg}^{-1} \\
0.75 \mu \mathrm{g} \mathrm{kg}^{-1} \\
\end{array}$ & $\begin{array}{c}\text { Wu et al., } 2011 \\
\text { Rodrigues et al., } 2010 \\
\text { Wu et al., } 2010 \\
\text { Filho et al., 2010b } \\
\text { Wang et al., 2010 } \\
\text { Filho et al., 2010a } \\
\text { Qu et al., 2010 }\end{array}$ \\
\hline Phosmet & $\begin{array}{c}\text { GC-MS } \\
\text { HPLC-DAD }\end{array}$ & $\begin{array}{c}\text { ASE } \\
\text { UASEME }\end{array}$ & $\begin{array}{l}0.50 \mu \mathrm{g} \mathrm{kg}^{-1} \\
0.10 \mu \mathrm{g} \mathrm{L}^{-1}\end{array}$ & $\begin{array}{l}\text { Wu et al., } 2011 \\
\text { Wu et al., } 2010 \\
\end{array}$ \\
\hline Phorate & $\begin{array}{c}\text { GC-MS } \\
\text { GC-QqQ MS/MS }\end{array}$ & $\begin{array}{c}\text { ASE } \\
\text { DSPE }\end{array}$ & $\begin{array}{l}0.70 \mu \mathrm{g} \mathrm{kg}^{-1} \\
0.62 \mu \mathrm{g} \mathrm{kg}^{-1}\end{array}$ & $\begin{array}{l}\text { Wu et al., } 2011 \\
\text { Qu et al., } 2010 \\
\end{array}$ \\
\hline Trichlorfon & $\begin{array}{l}\text { GC-MS } \\
\text { GC-MS }\end{array}$ & $\begin{array}{l}\text { SPME } \\
\text { ASE }\end{array}$ & $\begin{array}{l}0.07 \mu \mathrm{g} \mathrm{L}^{-1} \\
5.1 \mu \mathrm{g} \mathrm{kg}^{-1}\end{array}$ & $\begin{array}{l}\text { Filho et al., 2010b } \\
\text { Wu et al., } 2011\end{array}$ \\
\hline
\end{tabular}

Table 3. Analytical performances of some chromatographic methods applied to OP pesticides analysis, namely LOD. 


\subsection{Electrochemical methods for OP pesticides analysis}

The electrochemical activity of the OP pesticides containing nitro-phenyl groups: parathionmethyl, parathion, paraoxon, fenitrothion, etc. makes possible their direct electrochemical determination. The mechanism of the redox process, selecting parathion-methyl as a model, is the following:
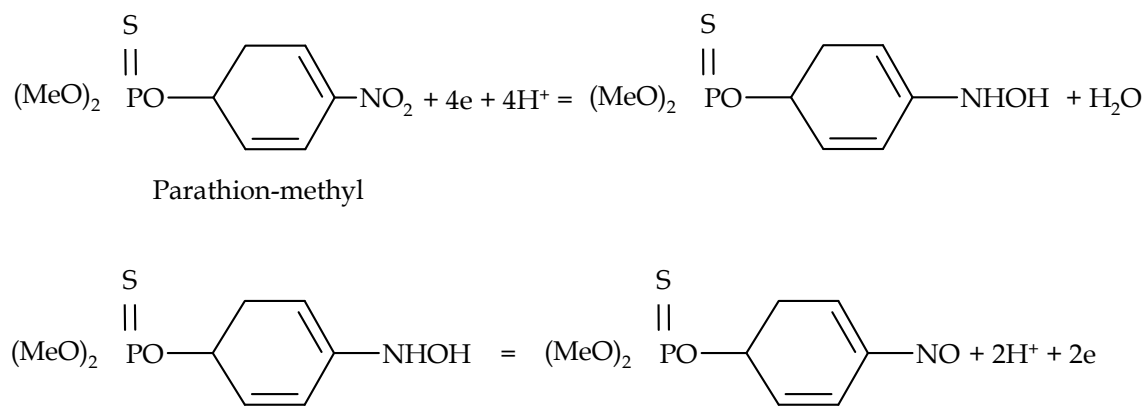

The electrochemical method of choice applied to OP pesticides analysis, considering the period 2005-2011, is square-wave voltammetry (Li and al., 2011; Parham and Rahbar, 2010; Sbaï et al., 2007; Tan et al., 2010; Wang and Li, 2008). It is recognized as a high sensitive regarding the detection of organic molecules. Current efforts are directed toward sensitivity and selectivity improvement by chemical modification of the electrode surface. The reported techniques include: nano- $\mathrm{ZrO}_{2}$ modification of a carbon paste electrode (Parham and Rahbar, 2010), fabrication of $\mathrm{ZrO}_{2} / \mathrm{Au}$ nano-composite films on alumina substrates (Wang and Li, 2008), electrodeposition of molecularly imprinted porous silicate (Tan et al., 2010) or of gold-sodium dodecylbenzene sulfonate nanoparticles onto a glassy carbon electrode ( $\mathrm{Li}$ and al., 2011a), tetrasulfonated phtalocyanine electrodeposition combined with Nafion coating of carbon fibres (Sbaï et al., 2007), etc. $\mathrm{ZrO}_{2}$ nanoparticles in particular, used as a selective sorbents for solid-phase extraction, demonstrate excellent performance in OP pesticides detection, because of their affinity toward the phosphate group on OP pesticide molecule (Parham and Rahbar, 2010; Wang and Li, 2008).

The developed electrochemical methods are applied for OP pesticides determination in pears (Li and al., 2011; Tan et al., 2010), and in water samples (Parham and Rahbar, 2010). Some relevant data revealing the sensitivity of the determinations are presented in Table 4.

\begin{tabular}{|c|c|c|c|c|}
\hline Pesticide & Electrode & Electrode modification & LOD & References \\
\hline Parathion-methyl & CFME & poly-NiTSPc/Nafion & $0.1 \mathrm{mg} \mathrm{L}^{-1}$ & Sbaï et al., 2007 \\
\hline Parathion-methyl & GC & imprinted silicate & $2.5 \mu \mathrm{g} \mathrm{L}^{-1}$ & Tan et al., 2010 \\
\hline Parathion-methyl & GC & nano-ZrO & $2.0 \mu \mathrm{g} \mathrm{L}^{-1}$ & Parham and Rahbar, 2010 \\
\hline Parathion-methyl & GC & nano-Au/SDBS & $25 \mu \mathrm{g} \mathrm{L}^{-1}$ & Li and al., 2011 \\
\hline Parathion & GC & $\mathrm{ZrO}_{2} / \mathrm{Au}$ & $3.0 \mu \mathrm{g} \mathrm{L}^{-1}$ & Wang and Li, 2008 \\
\hline
\end{tabular}

Table 4. Analytical performances of square wave voltammetry, applied to OP pesticides analysis, namely LOD.

The analysis of the reported studies confirms that the electrochemical methods have the advantage to be rapid, sensitive, selective, and accurate. In addition, they use affordable, portable, and miniaturized instrumentation. These characteristics make them appropriate for the "in field" determination of the low persistent in the environment OP pesticides. 


\subsection{Immunochemical methods for OP pesticides analysis}

Only few immunochemical methods for OP pesticides analysis were reported during the surveyed period 2005-2011. Gui and al. (2006) synthesize two haptens of the OP insecticide triazophos and develop an enzyme-linked immunosorbent assay based on monoclonal antibody, demonstrating high affinity and specificity to triazophos. Guo and al. (2009) investigate two formats of gold-labeled antibody lateral-flow strips for the simultaneous detection of triazophos and of the carbamate pesticide carbofuran. The application of the immunogold labeling technique in immunoassays is reviewed by Lai et al. (2010). GarcésGarcía and al. (2006) point out the development of plate immunoassays for routine determination of residues: diazinon, fenthion, malathion, and chlorpyrifos in extra virgin olive oil. The achieved by the mentioned methods LOD is shown in Table 5.

\begin{tabular}{|c|c|c|c|}
\hline Pesticide & Method & LOD & References \\
\hline Diazinon & ELISA & $46 \mu \mathrm{g} \mathrm{L}^{-1}$ & García and al., 2006 \\
\hline Fenthion & ELISA & $10 \mu \mathrm{g} \mathrm{L}^{-1}$ & García and al., 2006 \\
\hline Malathion & ELISA & $16 \mu \mathrm{g} \mathrm{L}^{-1}$ & García and al., 2006 \\
\hline Chlorpyrifos & ELISA & $17 \mu \mathrm{g} \mathrm{L}^{-1}$ & García and al., 2006 \\
\hline triazophos & ELISA & $0.1 \mu \mathrm{g} \mathrm{L}^{-1}$ & Gui and al., 2006 \\
\hline
\end{tabular}

Table 5. Analytical performances of some immunochemical methods, applied to OP pesticides analysis, namely LOD.

\subsection{Biosensors based methods for OP pesticides analysis}

The overview of the publications covering the period 2005-2011 shows that almost all of the described biosensors for OP pesticides analysis are electrochemical ones. The OP pesticides determination is based on the quantification of the acetylcholinesterase inhibition, they provoke. The enzyme activity is determined by electrochemically monitoring the thiocholine formed upon enzymatic hydrolysis of acetylthiocholine. Three alternative routes are explored as response-generating electrochemical reactions:

i. Direct electrochemical oxidation of thiocholine at $0.80 \mathrm{~V} / \mathrm{Ag}, \mathrm{AgCl}$ (Ivanov et al., 2010;

Marinov et al., 2010; Ovalle et al., 2009):

$2\left(\mathrm{CH}_{3}\right)_{3} \mathrm{~N}^{+}\left(\mathrm{CH}_{2}\right)_{2} \mathrm{SH} \rightarrow\left(\mathrm{CH}_{3}\right)_{3} \mathrm{~N}^{+}\left(\mathrm{CH}_{2}\right)_{2} \mathrm{~S}-\mathrm{S}\left(\mathrm{CH}_{2}\right)_{2} \mathrm{~N}^{+}\left(\mathrm{CH}_{3}\right)_{3}+2 \mathrm{H}^{+}+2 \mathrm{e}^{-}$

It is important to note that potential lowering and hence interferences elimination could be achieved by using nanostructured materials for electrode modification. Nanoparticles reduce the working potential by catalysing the electrochemical thiocholine oxidation ( $\mathrm{Du}, 2007)$.

ii. Mediated thiocholine oxidation at lower electrode potential $(0.1 \div 0.45 \mathrm{~V} / \mathrm{Ag}, \mathrm{AgCl})$, using cobalt phtalocyanine (Alonso et al., 2010; Law \& Higson, 2005), tetracyanoquinodimetane (Hildebrandt et al., 2008) or hexacyanoferrate (III) (Ovalle et al., 2009) as electron mediators in a heterogeneous or in a homogeneous phase:

$2\left(\mathrm{CH}_{3}\right)_{3} \mathrm{~N}^{+}\left(\mathrm{CH}_{2}\right)_{2} \mathrm{SH}+2 \mathrm{M}_{\mathrm{ox}} \rightarrow\left(\mathrm{CH}_{3}\right)_{3} \mathrm{~N}^{+}\left(\mathrm{CH}_{2}\right)_{2} \mathrm{~S}-\mathrm{S}\left(\mathrm{CH}_{2}\right)_{2} \mathrm{~N}^{+}\left(\mathrm{CH}_{3}\right)_{3}+2 \mathrm{M}_{\text {red }}$

$\mathrm{M}_{\mathrm{red}} \rightarrow \mathrm{M}_{\mathrm{ox}}+\mathrm{e}^{-}$

iii. Chemisorption of thiocholine at $-0.7 \mathrm{~V} / \mathrm{Ag}, \mathrm{AgCl}$ and electrochemical desorption in $\mathrm{KOH}$, giving a measurable reductive peak current (Du et al., 2008).

The majority of the publications report the application of screen-printed electrodes (Alonso et al., 2010; Dondoi et al., 2006; Hildebrandt et al., 2008, Law \& Higson, 2005) as transducers. Recent developments in the field of screen-printed electrodes and their related applications 
are comprehensively reviewed by Renedo et al. (2007). Disposable screen-printed electrodes are considered as an alternative to the traditional electrodes for "in situ" analysis.

As immobilization matrices in electrochemical acetylcholinesterase-based sensors for OP pesticides determination were preferentially used various nanomaterials: nanostructured polymer membranes with integrated multiwall carbon nanotubes (Ivanov et al., 2010) or gold nanoparticles (Marinov et al., 2010), multiwall carbon nanotubes-chitosan composite (Du et al., 2007), etc., to achieve sensitivity increase and sensor stability improvement. Recent trends and challenges in developing nanomaterials-based biosensors for OP pesticides detection are discussed by a number of authors (Balasubramanian \& Burghard, 2006; Eftekhari, 2008; Gorton, 2005; Guo \& Wang, 2007; Kerman et al., 2008; Kumar, 2007; Liu et al., 2008, Luo et al., 2006; Merkoçi \& Alegret, 2005; Merkoçi, 2009; Pumera et al., 2007, Wang \& Lin 2009).

The alternative route leading to biosensors sensitivity, selectivity and stability increase involves the incorporation in the biosensing platform of biorecognition elements with tailor designed properties. Genetically modified enzymes are extensively used in inhibition based biosensors for OP pesticides determination (Bucur et al., 2005; Marques et al., 2005; ValdésRamírez et al., 2008), allowing attaining LOD as low as 10-17 M (Sotiropoulou et al., 2005). Current research efforts are reviewed by Campás et al. (2009).

Another important issue associated with electrochemical biosensors development is that concerning chemometrics. It was demonstrated that artificial neural networks implementation could resolve mixtures of pesticides (Alonso et al., 2010).

Exhaustive reviews on enzyme inhibition-based biosensors, including inhibition determination in organic phase are provided by Amine et al. (2006) and López et al. (2006). The application of various enzymes: acetylcholinesterase, acid phosphatase, alkaline phosphatise, organophosphorus hydrolase, and tyrosinase for the quantification of OP pesticides in the environment is extensively revised by Van Dyk et al. (2011).

Another group of electrochemical biosensors for OP pesticides analysis is that of the microbial sensors. Such sensors, based on Clark dissolved oxygen electrode modified with recombinant p-nitrophenol degrading/oxidizing bacteria endowed with OPH activity were reported by Lei et al. $(2005,2006)$. The surface-displayed OPH catalyzes the hydrolysis of OP pesticides with nitrophenyl substituent to release products, metabolized by the bacteria while consuming oxygen. The oxygen consumption is measured and correlated to the OP concentration.

A microbial biosensor for direct determination of nitrophenyl-substituted organophosphate nerve agents using genetically engineered Moraxella sp. has been proposed by Mulchandani et al. (2006). However, the reached LOD is over the OP concentration in environmental samples and higher than that for acylcholinesterases inhibition-based sensors, immunoassays, and gas, liquid and thin layer chromatography (Mulchandani et al., 2006).

Recently, an electrochemical hybrid biosensor for OP pesticides trace level concentrations determination was developed and characterized (Stoytcheva et al., 2009). It integrates a hybrid biorecognition element consisting of immobilized Arthrobacter globiformis and free acetylcholinesterase (ACh) with a Clark type oxygen probe transducer. The bacteria convert the ACh-generated choline to betaine with oxygen consumption measured as a Clark probe current change. This change, representing the sensor response, correlates to the concentration of the OP pesticides inhibiting the Ach catalyzed acetylcholine hydrolysis to choline. Current progress in microbial electrochemical and optical biosensors are reported by $\mathrm{Su}$ and al. (2011). 
Finally, the few works commenting on optic- and immuno- biosensors development and application to OP pesticides analysis have to be pointed out, too (Llorent-Martínez et al., 2011; Mauriz et al., 2006a, 2006b; Suri et al., 2009). Special attention should be paid to the overview of Jiang and al. (2008), presenting the various transduction systems used in immunosensors: electrochemical, optical, piezoelectric, and nanomechanic, and the immobilization protocols.

Some relevant data are presented in Table 6.

\begin{tabular}{|c|c|c|c|}
\hline Pesticide & Electrochemical biosensor & LOD & References \\
\hline Azinphos & Ach/polyaniline carbon/cobalt phtalocyanine & $10^{-10} \mu \mathrm{M}$ & Law et al., 2005 \\
\hline Dichlorvos & Ach/polyaniline carbon/cobalt phtalocyanine & $10^{-11} \mu \mathrm{M}$ & Law et al., 2005 \\
\hline Chlorpyrifos-oxon & Ach/polyvinyl alcohol/TCNQ/C & $2 \mu \mathrm{g} \mathrm{L}^{-1}$ & $\begin{array}{c}\text { Hildebrandt et } \\
\text { al., 2008 }\end{array}$ \\
\hline Malathion & Ach/AuNPs/chitosan/Au & $0.03 \mu \mathrm{g} \mathrm{L}^{-1}$ & Du et al., 2008 \\
\hline Paraoxon & $\begin{array}{c}\text { Ach/MWCN/poly-(acrylonitrile-methyl- } \\
\text { methacrylate-sodium vinylsulfonate)/Pt }\end{array}$ & $1.39 \times 10^{-6} \mu \mathrm{g} \mathrm{L}^{-1}$ & Ivanov et al., 2010 \\
\hline Paraoxon & $\begin{array}{c}\text { Ach/AuNPs poly-(acrylonitrile-methyl- } \\
\text { methacrylate-sodium vinylsulfonate)/Pt }\end{array}$ & $7.39 \times 10^{-5} \mu \mathrm{g} \mathrm{L}^{-1}$ & $\begin{array}{c}\text { Marinov et al., } \\
2010\end{array}$ \\
\hline Parathion & Ach/polyaniline carbon/cobalt phtalocyanine & $10^{-10} \mu \mathrm{M}$ & Law et al., 2005 \\
\hline Triazophos & Ach/MWCNT-chitosan/GCE & $10^{-2} \mu \mathrm{M}$ & Du et al., 2007 \\
\hline
\end{tabular}

Table 6. Analytical performances of some biosensors-based methods, applied to OP pesticides analysis, namely LOD.

\subsection{Chemometrics applied to OP pesticides analysis}

Current progress on the application of chemometrics to evaluate the occurrence of organic pollutants, including OP pesticides in the environment are reviewed by Mas et al. (2010). The interpretation of the results of the analytical determination of these substances, applying chemometric approaches is among the addressed issues.

On the improvement of the electroanalytical techniques in particular with the aid of chemometrics (partial least squares, artificial neural networks, and multiple curve resolution methods) comment $\mathrm{Ni}$ and Kokot (2008). Some of the suggested methods are successfully applied to OP pesticides analysis.

The strategies for the enhancement of the spectroscopic photochemistry by chemometrics are discussed in the overview presented by Liu et al. (2009). The chemometric methods revealed their efficacy for the simultaneous and selective enzymatic spectrophotometric determination of carbamate (carbofuran, carbaryl) and OP pesticides (chlorpyrifos, dichlorfos, phoxim) (Ni and al., 2007; Rhouati and al., 2010), and for the simultaneous determination of OP pesticides residues: dipterex, dichlorvos and omethoate in vegerable samples by continuous-flow chemiluminescence without any previous separation ( $\mathrm{Li}$ et al., 2007).

\section{Conclusion}

The continuous lowering of the maximum residue limits of the OP pesticides in food and in the environment calls for the development of sensitive methods for their determination. Such high effective techniques, well suited for testing complex matrices, are the chromatographic ones. Nevertheless, the review of the advances in OP pesticides analysis 
during the period 2005-2011 demonstrated that despite of the efforts to reduce solvent consumption and to simplify sample pretreatment, the chromatographic determinations remain expensive and time consuming. In addition, they require experienced personnel and sophisticated laboratory equipment, inappropriate for "in field" application. Therefore, a number of alternative electrochemical and biosensors-based techniques were suggested. Because of the inexpensive instrumentation, the simple operation procedure without or with a minimum sample pretreatment, and the high sensitivity, they gain more and more importance in OP pesticides analyses, as an excellent complement to the classical analytical techniques, for "in situ" and "on line" determinations.

\section{List of abbreviations}

Ach: acetylcholinesterase; ASE: accelerated solvent extraction; AuNPs: gold nanoparticles; CFME: carbon fibre microelectrode; DSPE: dispersive solid phase extraction; ELISA: enzyme-linked immunosorbent assay; EPA: U.S. Environmental Protection Agency; FAO: Food and Agricultural Organization of the United Nations; FQPA: Food Quality Protection Act; GC: glassy carbon; GCE: glassy carbon electrode; GC-ECD: gas chromatography using electron-capture-detector; GC-QqQ-MS/MS: chromatography-triple quadrupole mass spectrometry; GC/PFPD: gas chromatography/pulsed flame photometric detector; HPLCDAD: highperformance liquid chromatography with diode array detection; HS-SPME: solidphase microextraction in mode headspace; LLE: liquid-liquid extraction; LLSE: liquid-liquid solvent extraction; LOD: limit of detection; M: mediator; MRLs: maximum residue limits; MWCN: multiwall carbon nanoparticles; MWCNT: multiwall carbon nanotubes; NiTSPc: nickel(II) tetrasulfonated phtalocyanine; OGWDW: U.S. Environmental Protection Agency Office of Ground Water and Drinking Water; OP: organophosphorus; OPH: organophosphoro hydrolase; QuEChERS method: quick, easy, cheap, effective, rugged and safe method; SDBS: sodium dodecylbenzene sulfonate; SE: solvent extraction; SPE: solid phase extraction; SPME: solid-phase microextraction; TCNQ: tetracyanoquinodimetane; TOTAD: through oven transfer adsorption desorption; UASEME: ultrasound-assisted surfactant-enhanced emulsification microextraction; WHO: World Health Organization.

\section{References}

Ahmadi, F.; Assadi, Y.; Hosseini, S.M.R. \& Rezaee, M. (2006). Determination of organophosphorus pesticides in water samples by single drop microextraction and gas chromatography-flame photometric detector. J. Chromatogr. A, 1101, 307-312

Akkad, R. \& Schwack, W. (2010). Multi-enzyme inhibition assay for the detection of insecticidal organophosphates and carbamates by high-performance thin-layer chromatography applied to determine enzyme inhibition factors and residues in juice and water samples. J. Chromatogr. B, 878, 1337-1345

Al-Degs, Y. S.; Al-Ghouti, M. A. \& El-Sheikh, A. H. (2009). Simultaneous determination of pesticides at trace levels in water using multiwalled carbon nanotubes as solidphase extractant and multivariate calibration. J. Hazard. Materials, 169, 128-135

Alonso, G.; Istamboulie, G.; Ramírez-García, A.; Noguer, T.; Marty, J-L. \& Muñoz, R. (2010). Artificial neural network implementation in single low-cost chip for the detection of insecticides by modeling of screen-printed enzymatic sensors response. Computers and Electronics in Agriculture, 74, 223-229 
Amine, A.; Mohammadi, H.; Bourais, I. \& Palleschi, G. (2006). Enzyme inhibition-based biosensors for food safety and environmental monitoring. Biosens. Bioelectron., 21, 1405-1423

Anastassiades, M.; Lehotay, S.; Štajnbaher, D.; \& Schenk, J. F. (2003). Fast and easy multiresidue method employing acetonitrile extraction/partitioning and "dispersive solid-phase extraction" for the determination of pesticide residues in produce. Journal of AOAC International, 86, 412-431

Balasubramanian, K. \& Burghard, M. (2006). Biosensors based on carbon nanotubes. Anal. Bioanal. Chem., 385, 452-468

Barco-Bonilla, N.; Romero-González, R.; Plaza-Bolaños, P.; Frenich, A. G. \& Vidal, J. L. M. (2010). Analysis and study of the distribution of polar and non-polar pesticides wastewater effluents from modern and conventional treatments. J. Chromatogr. A, $1217,7817-7825$

Baugros, J-B.; Giroud, B.; Dessalces, G.; Grenier-Loustalota, M-F. \& Cren-Olivé, C. (2008). Multiresidue analytical methods for the ultra-trace quantification of 33 priority substances present in the list of REACH in real water samples. Anal. Chim. Acta, $607,191-203$

Baugros, J-B.; Cren-Olivé, C.; Giroud, B.; Gauvrit, J-Y.; Lantéri, P. \& Grenier-Loustalot, M-F. (2009). Optimisation of pressurised liquid extraction by experimental design for quantification of pesticides and alkyl phenols in sludge, suspended materials and atmospheric fallout by liquid chromatography-tandem mass spectrometry. $J$. Chromatogr. A, 1216, 4941-4949

Beyer, A. \& Biziuk, M. (2008). Applications of sample preparation techniques in the analysis of pesticides and PCBs in food. Food Chemistry, 108, 669-680

Blasco, C.; Font, G. \& Picó, Y. (2005). Analysis of pesticides in fruits by pressurized liquid extraction and liquid chromatography-ion trap-triple stage mass spectrometry. $J$. Chromatogr. A, 1098, 37-43

Bucur, B.; Dondoi, M.; Danet, A. \& Marty, J.-L. (2005). Insecticide identification using a flow injection analysis system with biosensors based on various cholinesterases. Anal. Chim. Acta, 539, 1-2

Buonasera, K.; D’Orazio, G.; Fanali, S.; Dugo, P. \& Mondello, L. (2009). Separation of organophosphorus pesticides by using nano-liquid chromatography. J. Chromatogr. A, 1216, 3970-3976

Camino-Sánchez, F. J.; Zafra-Gómez, A.; Ruiz-García, J.; Bermúdez-Peinado, R.; Ballesteros, O.; Navalon, A. \& Vílchez, J. L. (2008). UNE-EN ISO/IEC 17025: 2005 accredited method for the determination of 121 pesticide residues in fruits and vegetables by gas chromatography tandem mass spectrometry, J. Food Composition and Analysis, doi:10.1016/j.jfca.2010.11.009 (in press)

Campàs, M; Prieto-Simón, B. \& Marty J.-L. (2009). A review of the use of genetically engineered enzymes in electrochemical biosensors. Seminars in Cell E Developmental Biology, 20, 1

Chai, M. K. \& Tan, G. T. (2009). Validation of a headspace solid-phase microextraction procedure with gas chromatography-electron capture detection of pesticide residues in fruits and vegetables. Food Chemistry, 117, 561-567

Chung, S. \& Chan, B. (2010) Validation and use of a fast sample preparation method and liquid chromatography-tandem mass spectrometry in analysis of ultra-trace levels 
of 98 organophosphorus pesticide and carbamate residues in a total diet study involving diversified food types. J. Chromatogr. A, 1217, 4815-4824

Chen, P-S. \& Huang, S-D. (2006). Determination of ethoprop, diazinon, disulfoton and fenthion using dynamic hollow fiber-protected liquid-phase microextraction coupled with gas chromatography-mass spectrometry. Talanta, 69, 669-675

Codex pesticides residues in food online database, Codex Alimentarius Commission, 22nd Session, June 1997, http:/ /www.codexalimentarius.net/mrls/pestdes/jsp/pest_qe.jsp (accessed on 09.01.2011)

Corbett, J. R.; Wright, K. \& Baillie, A. C. (1984). The biochemical mode of action of pesticides, 2nd ed., Academic press, London

Cortés-Aguado, S.; Sánchez-Morito, N.; Arrebola, F.J.; Frenich, A. G. \& Vidal, J. L. M. (2008). Fast screening of pesticide residues in fruit juice by solid-phase microextraction and gas chromatography-mass spectrometry. Food Chemistry, 107, 1314-1325

Council Directive 76/895/EEC (23 November 1976). Official Journal of the European Communities, 09.12.1976, L340

Council Directive 86/363/EEC (24 July 1986). Official Journal of the European Communities, 03.07.1986, L164

Council Directive 86/362/EEC (24 July 1986). Official Journal of the European Communities, 07.08.1986, L221

Council Directive 90/642/EEC (27 November 1990). Official Journal of the European Communities, 14.12.1990, L350

Council Directive 98/83/EC (3 November 1998). Official Journal of the European Communities, 5.12.1998, L330/32

Cunha, S. C.; Fernandes, J. O. \& Oliveira, M. B. P. P. (2009). Fast analysis of multiple pesticide residues in apple juice using dispersive liquid-liquid microextraction and multidimensional gas chromatography-mass spectrometry. J. Chromatogr. A, 1216, 8835-8844

Dagnac, T.; Garcia-Chao, M.; Pulleiro, P.; Garcia-Jares, C. \& Llompart, M. (2009). Dispersive solid-phase extraction followed by liquid chromatography-tandem mass spectrometry for the multi-residue analysis of pesticides in raw bovine milk. $J$. Chromatogr. A, 1216, 3702-3709

Díaz, L.; Llorca-Pórcel, J. \& Valor, I. (2008). Ultra trace determination of 31 pesticides in water samples by direct injection-rapid resolution liquid chromatographyelectrospray tandem mass spectrometry. Anal. Chim. Acta, 624, 90-96

Dondoi, M.; Bucur, B.; Danet, A.; Toader, C.; Barthelmebs, L. Marty, J-L. (2006). Organophosphorus insecticides extraction and heterogeneous oxidation on column for analysis with an acetylcholinesterase (AChE) biosensor. Anal. Chim. Acta, 578, 162-169

Du, D.; Huang, X.; Cai, J. \& Zhang, A. (2007). Amperometric detection of triazophos pesticide using acetylcholinesterase biosensor based on multiwall carbon nanotube-chitosan matrix. Sensors and Actuators B, 127, 531-535

Du, D.; Ding, J.; Tao, Y. \& Chen, X. (2008). Application of chemisorption/desorption process of thiocholine for pesticide detection based on acetylcholinesterase biosensor. Sensors and Actuators B, 134, 908-912 
Dugo, G.; Di Bella, G.; La Torre, L. \& Saitta, M. (2005). Rapid GC-FPD determination of organophosphorus pesticide residues in Sicilian and Apulian olive oil. Food Control, $16,435-438$

Dujaković, N.; Grujić, S.; Radišić, M.; Vasiljević, T. \& Laušević, M. (2010). Determination of pesticides in surface and ground waters by liquid chromatography-electrospraytandem mass spectrometry. Anal. Chim. Acta, 678, 63-72

Eddleston, M.; Buckley, N.; Eyer, P. \& Dawson, A. (2008). Management of acute organophosphorus pesticide poisoning. The Lancet, 371, 9612, 597-607

Eftekhari, A. (2008). Nanostructured materials in electrochemistry. Wiley-VCH, ISBN: 978-3-52731876-6, Weinheim

Eto, M. (1974). Organophosphorus pesticides: organic and biological chemistry, CRS Press, Cleveland

FAOSTAT: http:/ / faostat.fao.org/site/424/default.aspx\#ancor (accessed on 09.01.2011)

Fenoll, J.; Hellín, P.; Martínez, C.; Miguel, M. \& Flores, P. (2007). Multiresidue method for analysis of pesticides in pepper and tomato by gas chromatography with nitrogenphosphorus detection. Food Chemistry, 105, 711-719

Filho, A. M.; Santos, F. N. \& Pereira P. A. P. (2010a). Development, validation and application of a methodology based on solid-phase micro extraction followed by gas chromatography coupled to mass spectrometry (SPME/GC-MS) for the determination of pesticide residues in mangoes. Talanta, 81, 346-354

Filho, A. M.; Santos, F. N. \& Pereira P. A. P. (2010b). Development, validation and application of a method based on DI-SPME and GC-MS for determination of pesticides of different chemical groups in surface and groundwater samples. Microchemical Journal, 96, 139-145

FQPA (1996). H. Rept. 104-669, part 2, 104th Congress, 2nd sess., p. 6.

Frenich, A.; Vidal, J. L. M.; Cruz Sicilia, A. D.; González Rodríguez, M. J. \& Plaza Bolaños, P. (2006). Multiresidue analysis of organochlorine and organophosphorus pesticides in muscle of chicken, pork and lamb by gas chromatography-triple quadrupole mass spectrometry. Anal. Chim. Acta, 558, 42-52

Fuentes, E.; Báez, M. E. \& Quiñonez, A. (2008). Suitability of microwave-assisted extraction coupled with solid-phase extraction for organophosphorus pesticide determination in olive oil. J. Chromatogr. A, 1207, 38-45

Fuentes, E.; Báez, M. E. \& Díaz, J. (2009). Microwave-assisted extraction at atmospheric pressure coupled to different clean-up methods for the determination of organophosphorus pesticides in olive and avocado oil. J. Chromatogr. A, 1216, 88598866

Garcés-García, M.; Brun, E.; Puchades, R. and Maquieira, A. (2006). Immunochemical determination of four organophosphorus insecticide residues in olive oil using a rapid extraction process. Anal. Chim. Acta, 556, 347-354

García-Rodríguez, D.; Carro-Díaz, A. M.; Lorenzo-Ferreira, R. A. \& Cela-Torrijos, R. (2010). Determination of pesticides in seaweeds by pressurized liquid extraction and programmed temperature vaporization-based large volume injection-gas chromatography-tandem mass spectrometry. J. Chromatogr. A, 1217, 2940-2949

García-Valcárcel, A. I. \& Tadeo, J. L. (2009). A combination of ultrasonic assisted extraction with LC-MS/MS for the determination of organophosphorus pesticides in sludge. Anal. Chim. Acta, 641, 117-123 
Georgakopoulos, P.; Mylona, A.; Athanasopoulos, P.; Drosinos, E. \& Skandamis, P. (2009). Evaluation of cost-effective methods in the pesticide residue analysis of non-fatty baby foods. Food Chemistry, 115, 1164-1169

Gilbert-López, B.; García-Reyes, J. F. \& Molina-Díaz, A. (2009). Sample treatment and determination of pesticide residues in fatty vegetable matrices: A review. Talanta, 79, 109-128

González-Curbelo, M. A.; Hernández-Borges, J.; Ravelo-Pérez, L. M. \& Rodríguez-Delgado, M. A. (2011). Insecticides extraction from banana leaves using a modified QuEChERS method. Food Chemistry, 125, 1083-1090

González-Rodríguez, R. M.; Rial-Otero, R.; Cancho-Grande, B. \& Simal-Gándara, J. (2008). Determination of 23 pesticide residues in leafy vegetables using gas chromatography-ion trap mass spectrometry and analyte protectants. J. Chromatogr. A, 1196, 100-109

Gorton, L. (2005). Biosensors and modern biospecific analytical techniques. Elsevier, ISBN: 0-444$50715-9$

Guardia-Rubio, A.; Marchal-López, R. M.; Ayora-Cañada, M. J. \& Ruiz-Medina, A. (2007). Determination of pesticides in olives by gas chromatography using different detection systems. J. Chromatogr. A, 1145, 195-203

Gui, W. J.; Jin, R. Y.; Chen, Z. L.; Cheng, J. L. and Zhu, G. N. (2006). Hapten synthesis for enzyme-linked immunoassay of the insecticide triazophos. Anal. Biochem., 357, 9-14

Guo, S. \& Wang, E. (2007). Synthesis and electrochemical applications of gold nanoparticels. Anal. Chim. Acta, 598, 181-192

Guo, Y-R.; Liu, S-Y.; Gui, W-J. and Zhu, G-N. (2009). Gold immunochromatographic assay for simultaneous detection of carbofuran and triazophos in water samples. Anal. Biochem., 389, 32-39

Gupta, R. C. (Ed.) (2006). Toxicology of organophosphate \& carbamate compounds, $1^{\text {st }}$ ed., Elsevier Academic Press, London

Hassall, K. A. (1982). The chemistry of pesticides. Their metabolism, mode of action and uses in crop protection, Verlag Chemie, Weinheim, Deerfield Beach, Florida, Basel

Hassan, J.; Farahani, A.; Shamsipur, M \& Damerchili, F. (2010). Rapid and simple low density miniaturized homogeneous liquid-liquid extraction and gas chromatography/mass spectrometric determination of pesticide residues in sediment. J. Hazard. Materials, 184, 869-871

He, L.; Luo, X.; Xie,H., Wang, C.; Jiang, X. \& Lu, K. (2009). Ionic liquid-based dispersive liquid-liquid microextraction followed high-performance liquid chromatography for the determination of organophosphorus pesticides in water sample. Anal. Chim. Acta, 655, 52-59

Hernández, F.; Pozo, O. J.; Sancho, J. V.; Bijlsma, L.; Barreda, M. \& Pitarch, E. (2006). Multiresidue liquid chromatography tandem mass spectrometry determination of 52 non gas chromatography amenable pesticides and metabolites in different food commodities. J. Chromatogr. A, 1109, 242-252

Hernández, F.; Portolés, T.; Pitarch, E. \& López, F. J. (2010). Gas chromatography coupled to high resolution time-of-flight mass spectrometry to analyze trace-level organic compounds in the environment, food safety and toxicology. Trends in Analytical Chemistry, doi: 10.1016/j.trac.2010.11.007 (in press) 
Hildebrandt, A.; Bragos, R.; Lacorte, S. \&. Marty, J-L. (2008). Performance of a portable biosensor for the analysis of organophosphorus and carbamate insecticides in water and food. Sensors and Actuators B, 133, 195-201

Hyötyläinen, T. \& Riekkola, M.-L. (2008). Sorbent- and liquid-phase microextraction techniques and membrane-assisted extraction in combination with gas chromatographic analysis: A review. Anal. Chim. Acta, 614, 27-37

Ibrahim, W. A.; Farhani, H.; Sanagia, M \& Aboul-Eneinb, H. (2010). Solid phase microextraction using new sol-gel hybrid polydimethylsiloxane-2-hydroxymethyl18-crown-6-coated fiber for determination of organophosphorous pesticides. J. Chromatogr. A, 1217, 4890-4897

Inoue, S.; Saito, T.; Mase, H.; Suzuki, Y.; Takazawa, K.; Yamamoto, I. \& Inokuchi, S. (2007). Rapid simultaneous determination for organophosphorus pesticides in human serum by LC-MS. J. Pharm. Biomed. Analysis, 44, 258-264

Ivanov, Y; Marinov, I.; Gabrovska, K.; Dimcheva, N. \& Godjevargova, T. (2010). Amperometric biosensor based on a site-specific immobilization of acetylcholinesterase via affinity bonds on a nanostructured polymer membrane with integrated multiwall carbon nanotubes. J. Mol. Catalysis B: Enzymatic, 63, 141148

Jiang, X.; Li, D.; Xua, X.; Ying, Y.; Li, Y.; Ye, Z. \& Wang, J. (2008). Immunosensors for detection of pesticide residues. Biosens. Bioelectron., 23, 1577-1587

Kerman, K.; Saito, M.; Yamamura, S.; Takamura \& Y.; Tamiya, E. (2008). Nanomaterialbased electrochemical biosensors for medical applications. Trends Anal. Chem., 27, 585-592

Kiely, T.; Donaldson, D. \& Grube, A. (2004). Pesticides Industry Sales and Usage. 2000 and 2001 Market Estimates. Washington, DC: U.S. Environmental Protection Agency, Report No. EPA-733-R-99-001

Kolberg, D.; Prestes, O.; Adaime, M. \& Zanella, R. (2011). Development of a fast multiresidue method for the determination of pesticides in dry samples (wheat grains, flour and bran) using QuEChERS based method and GC-MS. Food Chemistry, 125, 1436-1442

Krieger, R. (Ed.) (2001). Handbook of pesticides toxicology. Principles and agents, 2nd ed., Academic Press, London

Kujawski, M. W. \& Namieśnik, J. (2010). Levels of 13 multi-class pesticide residues in Polish honeys determined by LCESI-MS/MS. Food Control, doi: 10.1016/j.foodcont. 2010.11.024 (in press)

Kumar, C. (2007). Nanomaterials for biosensors. Wiley-VCH, ISBN-10: 3-527-31388-5, ISBN-13: 978-3-527-31388-4, Weinheim

Kuster, M.; López de Alda, M. \& Barceló, D. (2009). Liquid chromatography-tandem mass spectrometric analysis and regulatory issues of polar pesticides in natural and treated waters. J. Chromatogr. A, 1216, 520-529

Lai, C.; Zeng, G-M.; Huang, D-L.; Feng, C-L.; Hu, S.; Su, F-F.; Zhao, M-H; Huang, C. \& Wei, Z. (2010). Detection based on immunogold labeling technique and its expected application in composting. Chin. J. Anal. Chem., 38, 909-914

Lavagnini, I.; Urbani, A. \& Magno, F. (2011). Overall calibration procedure via a statistically based matrix-comprehensive approach in the stir bar sorptive extraction-thermal 
desorption-gas chromatography-mass spectrometry analysis of pesticide residues in fruit-based soft drinks. Talanta, doi:10.1016/j.talanta.2010.12.004 (in press)

Law, K. \& Higson, S. (2005). Sonochemically fabricated acetylcholinesterase micro-electrode arrays within a flow injection analyser for the determination of organophosphate pesticides. Biosens. Bioelectron., 20, 1914-1924

Le Doux, M. (2011). Analytical methods applied to the determination of pesticide residues in foods of animal origin. A review of the past two decades. J. Chromatogr. A, doi:10.1016/j.chroma.2010.12.097 (in press)

Lee, J-M.; Park, J-W.; Jang, G-C.; Hwang, K-J. (2008). Comparative study of pesticide multiresidue extraction in tobacco for gas chromatography-triple quadrupole mass spectrometry. J. Chromatogr. A, 1187, 25-33

Lei, Y.; Mulchandani, P.; Chen, W. \& Mulchandani, A. (2005). Direct determination of pnitrophenyl substituent organophosphorus nerve agents using a recombinant Pseudomonas putida JS444-modified Clark oxygen electrode. J. Agric. Food Chem., 53, 3, 524-527

Lei, Y.; Mulchandani, P.; Chen, W. \& Mulchandani, A. (2006). Biosensor for direct determination of fenitrothion and EPN using recombinant Pseudomonas putida JS444 with surface expressed organophosphorus hydrolase. 1. Modified Clark oxygen electrode. Sensors, 6, 466-472

Lesueur, C.; Knittl, P.; Gartner, M.; Mentler, A. \& Fuerhacker, M. (2008a). Analysis of 140 pesticides from conventional farming foodstuff samples after extraction with the modified QuECheRS method. Food Control, 19, 906-914

Lesueur, C.; Gartner, M.; Mentler, A. \& Fuerhacker, M. (2008b). Comparison of four extraction methods for the analysis of 24 pesticides in soil samples with gas chromatography-mass spectrometry and liquid chromatography-ion trap-mass spectrometry. Talanta, 75, 284-293

Li, B.; He, Y. and $\mathrm{Xu}, \mathrm{C}$. (2007). Simultaneous determination of three organophosphorus pesticides residues in vegetables using continuous-flow chemiluminescence with artificial neural network calibration. Talanta, 72, 223-230

Li, C.; Wang, Z. and Zhana, G. (2011a). Electrochemical investigation of methyl parathion at gold-sodium dodecylbenzene sulfonate nanoparticles modified glassy carbon electrode. Colloids and Surfaces B: Biointerfaces, 82, 40-45

Li, J.; Zhang, H-F. \& Shi, Y-P. (2011b). Monitoring multi-class pesticide residues in fresh grape by hollow fiber sorptive extraction combined with gas chromatography-mass spectrometry. Food Chemistry, doi: 10.1016/j.foodchem.2010.12.148 (in press)

Libin, Liu; Hashi, Y.; Yaping, Q.; Haixia, Z. \& Jinming, L. (2006). Rapid analysis of multiresidual pesticides in agricultural products by gas chromatography-mass spectrometry. Chin. J. Anal. Chem., 34, 783-786

Liu, Min; Hashi, Y.; Song, Y. \& Lin, Jin-Ming (2005) Simultaneous determination of carbamate and organophosphorus pesticides in fruits and vegetables by liquid chromatography-mass spectrometry. J. Chromatogr. A, 1097, 183-187

Liu, Min; Hashi, Y.; Song, Y. \& Lin, J-M. (2006). Determination of carbamate and organophosphorus pesticides in fruits and vegetables using liquid chromatography-mass spectrometry with dispersive solid phase extraction. Chin. J. Anal. Chem., 34, 941-945 
Liu, S.; Yuan, L.; Yue, X.; Zheng, Z. \& Tang, Z. (2008). Recent advances in nanosensors for organophosphate pesticide detection. Advanced Powder Technology, 19, 419-441

Liu, S.; Kokot, S. and Will, G. (2009). Photochemistry and chemometrics - an overview. J. Photochem. Photobiol. C: Photochem. Reviews., 10, 159-172

Llorent-Martínez, E. J.; Ortega-Barrales, P.; Fernández-de Córdova, M. L. \& Ruiz-Medina, A. (2011). Trends in flow-based analytical methods applied to pesticide detection: A review. Anal. Chim. Acta, 684, 30-39

López, M.; López-Cabarcos, E. \& López-Ruiz, B. (2006). Organic phase enzyme electrodes. Biomol. Engin., 23, 135-147

López-Feria, S; Cárdenas, S. \& Valcárcel, M. (2009). One step carbon nanotubes-based solidphase extraction for the gas chromatographic-mass spectrometric multiclass pesticide control in virgin olive oils. J. Chromatogr. A, 1216, 7346-7350

Luo, X.; Morrin, A.; Killard, A. \& Smyth, M. (2006). Application of nanoparticles in electrochemical sensors and biosensors. Electroanalysis, 18, 319-326

Malik, A. K.; Blasco, C. \& Picó, Y. (2010). Liquid chromatography-mass spectrometry in food safety. J. Chromatogr. A, 1217, 4018-4040

Marinov, I.; Ivanov, Y; Gabrovska, K. \& Godjevargova, T. (2010). Amperometric acetylthiocholine sensor based on acetylcholinesterase immobilized on nanostructured polymer membrane containing gold nanoparticles. J. Mol. Catalysis B: Enzymatic, 62, 67-75

Marques, P.; Nunes, G. S.; Rodrigues dos Santos, T. C.; Andreescu \& S. Marty, J-L. (2004). Comparative investigation between acetylcholinesterase obtained from commercial sources and genetically modified Drosophila melanogaster: Application in amperometric biosensors for methamidophos pesticide detection. Biosens. Bioelectron., 20, 825-832

Mas, S.; Juan, A.; Tauler, R.; Olivieri, A. and Escandar, G. (2010). Application of chemometric methods to environmental analysis of organic pollutants: a review. Talanta, 80, 1052-1067

Mauriz, E.; Calle, A.; Montoya, A. \& Lechuga, L. M. (2006a). Determination of environmental organic pollutants with a portable optical immunosensor. Talanta, $69,359-364$

Mauriz, E.; Calle, A.; Lechuga, L. M.; Quintana, J.; Montoya, A. \& Manclús, J. J. (2006b). Real-time detection of chlorpyrifos at part per trillion levels in ground, surface and drinking water samples by a portable surface plasmon resonance immunosensor. Anal. Chim. Acta, 561, 40-47

Merkoçi, A. \& Alegret, S. (2005). Toward nanoanalytical chemistry: case of nanomaterial integration into (bio)sensing systems. Contributions to science, 3, 57-66

Merkoçi, A. (2009). Biosensing using nanomaterials. Wiley- ISBN: 978-0-470-18309-0, Hoboken, New Jersey

Mulchandani, P.; Chen, W. \& Mulchandani, A. (2006). Microbial biosensor for direct determination of nitrophenyl-substituted organophosphate nerve agents using genetically engineered Moraxella sp. Anal. Chim. Acta, 568, 217-221

Nguyen, T. D.; Yu, J. E.; Lee, D. M. \& Lee, G-H. (2008). A multiresidue method for the determination of 107 pesticides in cabbage and radish using QuEChERS sample preparation method and gas chromatography mass spectrometry. Food Chemistry, 110, 207-213 
Nguyen, T. D.; Lee, M. H. \& Lee, G. H. (2010). Rapid determination of 95 pesticides in soybean oil using liquid-liquid extraction followed by centrifugation, freezing and dispersive solid phase extraction as cleanup steps and gas chromatography with mass spectrometric detection. Microchemical Journal, 95, 113-119

Ni, Y.; Cao, D. and Kokot, S. (2007). Simultaneous enzymatic kinetic determination of pesticides, carbaryl and phoxim, with the aid of chemometrics. Anal. Chim. Acta, 588, 131-139

Ni, Y. and Kokot, S. (2008). Does chemometrics enhance the performance of electroanalysis? Anal. Chim. Acta, 626, 130-146

Ovalle, M.; Stoytcheva, M.; Zlatev, R. \& Valdez, B. (2009). Electrochemical study of rat brain acetylcholinesterase inhibition by chlorofos: Kinetic aspects and analytical applications. Electrochim. Acta, 55, 516-520

Pagliuca, G.; Gazzotti, T.; Zironi, E. \& Sticca, P. (2005). Residue analysis of organophosphorus pesticides in animal matrices by dual column capillary gas chromatography with nitrogen-phosphorus detection. J. Chromatogr. A, 1071 67-70

Pang, Guo-Fang; Cao, Yan-Zhong; Zhang, Jin-Jie; Fan, Chun-Lin; Liu, Yong-Ming; Li, XueMin; Jia, Guang-Qun; Li, Zeng-Yin; Shi, Yu-Qiu; Wu, Yan-Ping \& Guo, Tong-Tong (2006). Validation study on 660 pesticide residues in animal tissues by gel permeation chromatography cleanup/gas chromatography-mass spectrometry and liquid chromatography-tandem mass spectrometry. J. Chromatogr. A, 1125, 1-30

Pareja, L.; Fernández-Alba, A. R.; Cesio, V. \& Heinzen, H. (2010). Analytical methods for pesticide residues in rice. Trends in Analytical Chemistry, doi: 10.1016/j.trac.2010.12.001 (in press)

Parham, H. and Rahbar, N. (2010). Square wave voltammetric determination of methyl parathion using $\mathrm{ZrO}_{2}$-nanoparticles modified carbon paste electrode. Journal of Hazardous Materials, 177, 1077-1084

Pérez-Ruiz, T.; Martínez-Lozano, C.; Tomas, V. \& Martín, J. (2005). High-performance liquid chromatographic assay of phosphate and organophosphorus pesticides using a post-column photochemical reaction and fluorimetric detection. Anal. Chim. Acta, 540, 383-391

Petrovic, M.; Farré, M.; López de Alda, M.; Pérez, S.; Postigo, S.; Köck, M.; Radjenovic, J.; Gros, M. \& Barceló, D. (2010). Recent trends in the liquid chromatography-mass spectrometry analysis of organic contaminants in environmental samples. $J$. Chromatogr. A, 1217, 4004-4017

Picó, Y.; Fernández, M.; Ruiz, M. \& Font, G. (2007). Current trends in solid-phase-based extraction techniques for the determination of pesticides in food and environment. J. Biochem. Biophys. Methods, 70, 117-131

Pinheiro, A. S. \& Andrade, J. B. (2009). Development, validation and application of a SDME/GC-FID methodology for the multiresidue determination of organophosphate and pyrethroid pesticides in water. Talanta, 79, 1354-1359

Pinho, G. P.; Neves, A. A.; Queiroz, M. E. \& Silvério, F. O. (2010). Optimization of the liquid-liquid extraction method and low temperature purification (LLE-LTP) for pesticide residue analysis in honey samples by gas chromatography. Food Control, 21, 1307-1311 
Pinto, M. I.; Sontag, G.; Bernardino, R. J. \& Noronha, J.P. (2010). Pesticides in water and the performance of the liquid-phase microextraction based techniques. A review. Microchemical Journal, 96, 225-237

Pinxteren, née Schellin, M.; Bauer, C. \& Popp, P. (2009). High performance liquid chromatography-tandem mass spectrometry for the analysis of 10 pesticides in water: A comparison between membrane-assisted solvent extraction and solid phase extraction. J. Chromatogr. A, 1216, 5800-5806

Portolés, T.; Pitarch, E.; López, F. J. \& Hernández, F. (2011). Development and validation of a rapid and wide-scope qualitative screening method for detection and identification of organic pollutants in natural water and wastewater by gas chromatography time-of-flight mass spectrometry. J. Chromatogr. A, 1218, 303-315

Przybylski, C. \& Hommet, F. (2008). Evaluation of some parameters affecting troublesome pesticide analysis in gas chromatography-ion-trap mass spectrometry. J. Chromatogr. A, 1201, 78-90

Pumera, M; Sánchez, S.; Ichinose, I. \& Tang, J. (2007). Electrochemical nanobiosensors. Sensors Actuators B, 123, 1195-1205

Qu, Lin-Juan; Zhang, Hui; Zhu, Jian-Hua; Yang, Guo-Sheng \& Aboul-Enein, H. Y. (2010). Rapid determination of organophosphorous pesticides in leeks by gas chromatography-triple quadrupole mass spectrometry. Food Chemistry, 122, 327332

Quin, L. D. (2000). A guide to organophosphorus chemistry, Wiley-Interscience

Radišić, M.; Grujić, S.; Vasiljević, T. \& Laušević, M. (2009). Determination of selected pesticides in fruit juices by matrix solid-phase dispersion and liquid chromatography-tandem mass spectrometry. Food Chemistry, 113, 712-719

Ramos, J. J.; González, M. J. \& Ramos, L. (2009). Comparison of gas chromatography-based approaches after fast miniaturized sample preparation for the monitoring of selected pesticide classes in fruits. J. Chromatogr. A, 1216, 7307-7313

Ravelo-Pérez, L. M.; Hernández-Borges, J. \& Rodríguez-Delgado, M. A. (2008). Multi-walled carbon nanotubes as efficient solid-phase extraction materials of organophosphorus pesticides from apple, grape, orange and pineapple fruit juices. J. Chromatogr. A, $1211,33-42$

Reg. (EC) No 396/2005, http://ec.europa.eu/sanco_pesticides/public/index.cfm (accessed on 09.01 .2011 )

Renedo, O.; Alonso-Lomillo, A. \& Martínez, M. J. A. (2007). Recent developments in the field of screen-printed electrodes and their related applications. Talanta, 73, 202-219

Rhouati, A.; Istamboulie, G.; Cortina-Puig, M.; Marty, J-L. \& Noguer, T. (2010). Selective spectrophotometric detection of insecticides using cholinesterases, phosphotriesterase and chemometric analysis. Enzyme Microb. Technol., 46, 212-216

Rial-Otero, R.; Gaspar, E. M.; Moura, I. \& Capelo J. L. (2007). Chromatographic-based methods for pesticide determination in honey: An overview. Talanta, 71, 503-514

Roberts, D. \& Aaron, C. (2007). Management of acute organophosphorus pesticide poisoning. BMJ, 334, 7594, 629-634

Rodrigues, F. M.; Mesquita, P.; Oliveira, L. S.; Oliveira, F. S.; Filho, A. M.; Pereira, P. A. \& Andrade, B. J. (2010). Development of a headspace solid-phase microextraction/gas chromatography-mass spectrometry method for determination of 
organophosphorus pesticide residues in cow milk. Microchem. J. doi: 10.1016/j.microc.2010.11.002 (in press)

Salma, P.; Taylor, P.; Roberts, D. \& Silva, J. (2009). Liquid chromatography-tandem mass spectrometry method for the simultaneous quantitative determination of the organophosphorus pesticides dimethoate, fenthion, diazinon and chlorpyrifos in human blood. J. Chromatogr. B, 877, 568-574

Sbaï, M.; Essis-Tome, H; Gombert, U.; Breton, T. and Pontié, M. (2007). Electrochemical stripping analysis of methyl-parathion (MPT) using carbon fiber microelectrodes (CFME) modified with combinations of poly-NiTSPc and Nafion ${ }^{\circledR}$ films. Sensors and Actuators B, 124, 368-375

Sharma, D.; Nagpal, A.; Pakade, Y. \& Katnoria J. (2010). Analytical methods for estimation of organophosphorus pesticide residues in fruits and vegetables: A review. Talanta, 82, 1077-1089

Silva, M.; Aquino, A.; Dórea, H. \& Navickiene, S. (2008). Simultaneous determination of eight pesticide residues in coconut using MSPD and GC/MS. Talanta, 76, 680-684

Sinha, S. N.; Pal, R. ; Dewan, A.; Mansuri, M.M. \& Saiyed, H.N. (2006). Effect of dissociation energy on ion formation and sensitivity of an analytical method for determination of chlorpyrifos in human blood, using gas chromatography-mass spectrometer (GC-MS in MS/MS). Int. J. Mass Spectrometry, 253, 48-57

Sinha, S. N.; Vasudev, K.; Rao, M. V. V. \& Odetokun, M. (2010). Quantification of organophosphate insecticides in drinking water in urban areas using lyophilization and high-performance liquid chromatography-electrospray ionization-mass spectrometry techniques. Int. J. .Mass Spectrom., doi:10.1016/j.ijms.2010.11.006 (in press)

Soler, C. \& Picó, Y. (2007). Recent trends in liquid chromatography-tandem mass spectrometry to determine pesticides and their metabolites in food. Trends in Analytical Chemistry, 26, 103-115

Sotiropoulou, S.; Fournier, D. \& Chaniotakis, N. (2005). Genetically engineered acetylcholinesterase-based biosensor for attomolar detection of dichlorvos. Biosens. Bioelectron., 20, 2347-2352

Stoytcheva, M.; Zlatev, R.; Velkova, Z.; Valdez, B.; Ovalle, M. \& Petkov, L. (2009). Hybrid electrochemical biosensor for organophosphorus pesticides quantification. Electrochim. Acta, 54, 1721-1727

Su, L.; Jia, W.; Hou, C. \& Lei, Y. (2011). Microbial biosensors: a review. Biosens. Bioelectr., 26, 1788-1799

Suri, C. R.; Boro, R.; Nangia, Y.; Gandhi, G.; Sharma, P.; Wangoo, N.; Rajesh, K. \&. Shekhawat, G. S. (2009). Immunoanalytical techniques for analyzing pesticides in the environment. Trends in Anal. Chem., 28, 29-39

Tan, X.; Li, B., Liew, K. Y. and Li, C. (2010). Electrochemical fabrication of molecularly imprinted electrode for fast and selective response of methyl parathion. Biosens. Bioelectron., 26, 868-871

Toledano, R.; Cortes, J.; Andini, J.; Villén, J \& Vázquez, A. (2010). Large volume injection of water in gas chromatography-mass spectrometry using the Through Oven Transfer Adsorption Desorption interface: Application to multiresidue analysis of pesticides. J. Chromatogr. A, 1217, 4738-4742 
Tsoutsi, C.; Konstantinou, I.; Hela, D. \& Albanis, T. (2006). Screening method for organophosphorus insecticides and their metabolites in olive oil samples based on headspace solid-phase microextraction coupled with gas chromatography. Anal. Chim. Acta, 573-574, 216-222

Valdés-Ramírez, G.; Fournier, D.; Ramírez-Silva, M. T. \& Marty, J-L. (2008). Sensitive amperometric biosensor for dichlorovos quantification: Application to detection of residues on apple skin. Talanta, 74, 741-746

Van Dyk, J. S. \& Pletschke, B. (2011). Review on the use of enzymes for the detection of organochlorine, organophosphate and carbamate pesticides in the environment. Chemosphere, 82, 291-307

Walorczyk, S. (2008). Development of a multi-residue method for the determination of pesticides in cereals and dry animal feed using gas chromatography-tandem quadrupole mass spectrometry. II. Improvement and extension to new analytes. J. Chromatogr. A, 1208, 202-214

Walorczyk, S., \& Gnusowski, B. (2009). Development and validation of a multi-residue method for the determination of pesticides in honeybees using acetonitrile-based extraction and gas chromatography-tandem quadrupole mass spectrometry. $J$. Chromatogr. A, 121, 6522-6531

Wang, J. \& Lin, Y. (2009). In: Nanotechnology application for clean water. Savage, N.; Diallo, M.; Duncan. J.; Street, A. \& Sustich, R. (Ed.), 377-390, William Andrew Pub., U.S.

Wang, M. and $\mathrm{Li}, \mathrm{Z}$. (2008). Nano-composite $\mathrm{ZrO}_{2} / \mathrm{Au}$ film electrode for voltammetric detection of parathion. Sensors and Actuators B, 133, 607-612

Wang, S.; Zhao, P.; Min, G. \& Fang, G. (2007). Multi-residue determination of pesticides in water using multi-walled carbon nanotubes solid-phase extraction and gas chromatography-mass spectrometry. J. Chromatogr. A, 1165, 166-171

Wang, Y. \& Du, R. (2010). Simultaneous extraction of trace organophosphorous pesticides from plasma sample by automated solid phase extraction and determination by gas chromatography coupled with pulsed flame photometric detector. Forensic Science International, 198, 70-73

Wang, Y.; Jin, Hong-Yu; Ma, Shuang-Cheng; Lu, Jing \& Lin, Rui-Chao (2011). Determination of 195 pesticide residues in Chinese herbs by gas chromatography-mass spectrometry using analyte protectants. J. Chromatogr. A, 1218, 334-342

WHO/IPCS. (1986). Organophosphorus insecticides: a general introduction (Environmental health criteria Series No 63), ISBN-10: 92-4-154263-2, ISBN-13: 978-92-4-154263-0, Geneva

Wu, C.; Liu, N.; Wu, Q.; Wang, C. \& Wang, Z. (2010). Application of ultrasound-assisted surfactant-enhanced emulsification microextraction for the determination of some organophosphorus pesticides in water samples. Anal. Chim. Acta, 679, 56-62

Wu, G.; Bao, X.; Zhao, S.; Wu, J.; Han, A. \& Ye, Q. (2011). Analysis of multi-pesticide residues in the foods of animal origin by GC-MS coupled with accelerated solvent extraction and gel permeation chromatography cleanup. Food Chemistry, 126, 646654

Xiao, Q.; Hu, B.; Yu, C.; Xia, L. \& Jiang, Z. (2006). Optimization of a single-drop microextraction procedure for the determination of organophosphorus pesticides in water and fruit juice with gas chromatography-flame photometric detection. Talanta, 69, 848-855 
Yang, X.; Zhang, H.; Liu, Y.; Wang, J.; Zhang, Y. C.; Dong, A. J.; Zhao, H. T.; Sun, C. H. \& Cui, J. (2011). Multiresidue method for determination of 88 pesticides in berry fruits using solid-phase extraction and gas chromatography-mass spectrometry Determination of 88 pesticides in berries using SPE and GC-MS. Food Chemistry, doi: 10.1016/j.foodchem.2011.01.024 (in press)

Yusà, V; Coscollà, C; Mellouki, W.; Pastor, A. \& de la Guardia, M. (2009). Sampling and analysis of pesticides in ambient air. J. Chromatogr. A, 1216, 2972-2983

Zhao, W-j.; Sun, X-k.; Deng, X-n.; Huang, L.; Yang, M-m. \& Zhou, Z-m. (2011). Cloud point extraction coupled with ultrasonic-assisted back-extraction to determination of organophosphorus pesticides in concentrated fruit juice by gas chromatography with flame photometric detection. Food Chemistry, doi: 10.1016/j.foodchem. 2010.12.122 (in press)

Zhu, H-Z.; Cui, Y-M.; Zheng, X-W.; Han, H-R. \& Yang, M-M. (2007). Determination of trace trichlorfon by high performance liquid chromatography with UV detection based on its catalytic effect on sodium perborate oxidizing benzidine. Anal. Chim. Acta, 584 166-171 


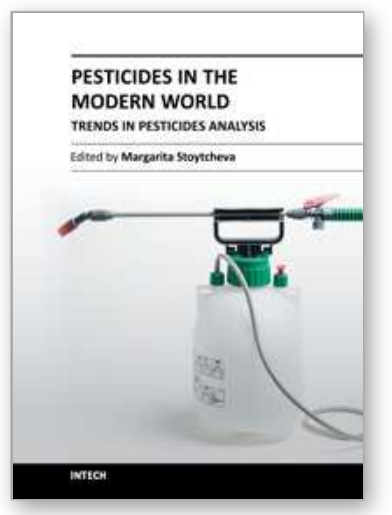

\author{
Pesticides in the Modern World - Trends in Pesticides Analysis \\ Edited by Dr. Margarita Stoytcheva
}

ISBN 978-953-307-437-5

Hard cover, 514 pages

Publisher InTech

Published online 21, October, 2011

Published in print edition October, 2011

The book offers a professional look on the recent achievements and emerging trends in pesticides analysis, including pesticides identification and characterization. The 20 chapters are organized in three sections. The first book section addresses issues associated with pesticides classification, pesticides properties and environmental risks, and pesticides safe management, and provides a general overview on the advanced chromatographic and sensors- and biosensors-based methods for pesticides determination. The second book section is specially devoted to the chromatographic pesticides quantification, including sample preparation. The basic principles of the modern extraction techniques, such as: accelerated solvent extraction, supercritical fluid extraction, microwave assisted extraction, solid phase extraction, solid phase microextraction, matrix solid phase dispersion extraction, cloud point extraction, and QuEChERS are comprehensively described and critically evaluated. The third book section describes some alternative analytical approaches to the conventional methods of pesticides determination. These include voltammetric techniques making use of electrochemical sensors and biosensors, and solid-phase spectrometry combined with flow-injection analysis applying flow-based optosensors.

\title{
How to reference
}

In order to correctly reference this scholarly work, feel free to copy and paste the following:

Margarita Stoytcheva and Roumen Zlatev (2011). Organophosphorus Pesticides Analysis, Pesticides in the Modern World - Trends in Pesticides Analysis, Dr. Margarita Stoytcheva (Ed.), ISBN: 978-953-307-437-5, InTech, Available from: http://www.intechopen.com/books/pesticides-in-the-modern-world-trends-in-pesticidesanalysis/organophosphorus-pesticides-analysis

\section{INTECH}

open science | open minds

\section{InTech Europe}

University Campus STeP Ri

Slavka Krautzeka 83/A

51000 Rijeka, Croatia

Phone: +385 (51) 770447

Fax: +385 (51) 686166

www.intechopen.com

\section{InTech China}

Unit 405, Office Block, Hotel Equatorial Shanghai

No.65, Yan An Road (West), Shanghai, 200040, China

中国上海市延安西路65号上海国际贵都大饭店办公楼405单元

Phone: +86-21-62489820

Fax: +86-21-62489821 
(C) 2011 The Author(s). Licensee IntechOpen. This is an open access article distributed under the terms of the Creative Commons Attribution 3.0 License, which permits unrestricted use, distribution, and reproduction in any medium, provided the original work is properly cited. 